\title{
ASPECTS OF THE REMUNERATION OF BLACK WORKERS IN SOUTH AFRICA: SOME RESEARCH FINDINGS
}

\author{
H.P. LANGENHOVEN \\ DEPARTMENT OF INDUSTRIAL PSYCHOLOGY \\ UNIVERSITY OF THE ORANGE FREE STATE
}

\section{OPSOMMING}

Verslag word gelewer oor die belangrikste bevindings van 'n vraelysondersoek by werkgewers oor die vergoeding van Swart werknemers in Suid-Afrika. Daar is onder meer bevind:

- dat die meeste van die gewone grensvoordele reeds taamlik algemeen aangebied word, of dat werkgewers bewus is van die nodigheid daarvan;

- dat lone nou saamhang met posvlakke en met opvoedkundige peil, wat albei verhoog sal moet word om die loongaping te vernou;

- dat werkgewers oor die algemeen 'n gesonde benadering toon tot die vergoeding van hulle Swart werkers maar blykbaar behoefte het aan 'n stelsel waarvolgens dit op 'n gesonde manier gedoen kan word.

\section{INTRODUCTION}

Recently, for various reasons, there has been more than normal interest in the remuneration of Black workers in South Africa. People with an objective interest in this matter may find it useful to obtain certain facts and views collected systematically.

\section{PURPOSE AND METHOD}

A country-wide survey on various matters pertaining to the remuneration of Black workers in South Africa was carried out in 1976. The purpose was to serve as a basis for the development of a new remuneration-system. The survey was done by the Personnel Research Division of the University of the Orange Free State as part of a series of investigations into the utilisation of Black labour. 
Information was collected by means of a questionnaire which was sent out to 310 organisations; only 114 of these questionnaires were completed and returned, of which 109 were suitable for analysis.

The companies included had a total staff of 457170 . Of these $37,8 \%$ were Whites, 53,8 \% Blacks and 8,4 \% Coloureds and Asians. This compares with 18,8 \% Whites, 70,1 \% Blacks, $8,8 \%$ Coloureds and 2,3\% Asians in the economically active population (1970 Census). During the last three years the number of Whites in these companies have remained more or less the same, while Blacks have increased by 9,6\% and Coloureds and Asians by $15,5 \%$.

Although it cannot be claimed that the sample is representative, the writer is of opinion that the results are non the less significant. This report will only contain some of the most relevant findings of the empirical investigation. The complete report has been published separately (Langenhoven, 1977).

\section{RESULTS}

\section{Fringe benefits}

Fringe benefits constitute an important part of the total compensation package. We were interested to know to what extent these were already used, or to what extent they were considered a need. These percentages are given in Table 1. 


\section{TABLE 1}

\section{FRINGE BENEFITS FOR BLACK WORKERS GRANTED AND CONSIDERED A NEED $(\mathrm{N}=109)$}

\begin{tabular}{|l|c|c|}
\hline & GRANTED \% & A NEED \% \\
\hline Medical aid & 43,1 & 40,4 \\
Pension scheme & 76,2 & 21,1 \\
Paid sick leave & 89,9 & 6,4 \\
Holiday bonuses & 67,0 & 17,4 \\
Production or merit bonuses & 34,9 & 28,4 \\
Long service bonuses & 53,2 & 20,2 \\
Housing benefits & 29,4 & 38,5 \\
Transport allowance & 35,8 & 22,0 \\
Feeding schemes & 53,2 & 25,7 \\
Work clothes or allowance & 86,2 & 9,2 \\
Educational scheme & 37,6 & 28,4 \\
Purchasing facilities & 35,8 & 16,5 \\
Recreational facilities & 35,8 & 34,9 \\
Saving schemes & 30,3 & 29,4 \\
\hline
\end{tabular}

From this data it is evident that several fringe benefits are already fairly generally available to Black workers.

These include some of the less common benefits such as feeding schemes $(53,2 \%)$, educational schemes $(37,6 \%)$, recreational facilities $(35,8 \%)$, transport allowances $(35,8 \%)$ and housing benefits $(29,4 \%)$. Furthermore, it is clear that large percentages of those who have not yet instituted these benefits, are already aware of the need for them, and probably considering making provision for them.

This seems to indicate that most employers are conscious of the non-monetary needs of their Black employees, and willing to incur large expenditures to satisfy these needs. In fact, it was found in another part of the investigation that the fringe benefits for the lowest paid workers constituted 16,0 \% of their basic wage, while for the highest paid workers it was only $10,7 \%$. This seems to indicate a concern for the welfare of the less privileged who are probably not able to earn more, probably as a result of lower educational qualifications.

It is clear from these figures that Black employees are not only compensated by basic wages, but that fringe benefits of various kinds constitute a considerable part of their total remuneration. In developing a compensation system this will have to be taken into account. 


\section{Compensation procedures}

Table 2 shows to what extent several systems and procedures are already in use for Black workers, and to what extent they are recognised as a need.

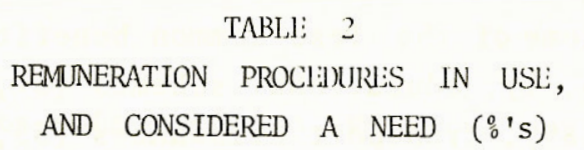

\begin{tabular}{|l|c|c|}
\hline & IN USE & A NEED \\
\cline { 2 - 3 } A formal job evaluation system & 43,0 & 38,3 \\
Salary and wage surveys & 67,3 & 13,1 \\
A system of equal pay for equal work & 43,0 & 21,5 \\
Equal pay for males and females & 27,1 & 22,4 \\
A job structure with jobs on different levels & 75,7 & 20,6 \\
Job scales along which employees can progress & 77,6 & 15,9 \\
Progress on job scales according to merit & 64,5 & 27,1 \\
\hline
\end{tabular}

From table 2 it is evident that several different remuneration systems and procedures are already in general use. There is also a need expressed by certain participants for some of these systems. However, it is not known how effective these systems are at present. It is also clear that salary and wage surveys are being more commonly used than job evaluation systems. Both, however, are actually needed in order to supplement one another.

\section{Job scales and wage structures}

To obtain some information on the wage structures of Black workers, our respondents were asked to provide a list of all the Black workers' job scales, from the lowest to the highest. From this data it appeared that:

- $\quad$ the average number of job scales for Blacks per firm was 6,3; thus indicating that they are not all paying everybody the same wage;

- $\quad$ the average increase within job scales was $37,8 \%$;

- $\quad$ that the average overlap between job scales was $13,8 \%$, i.e. the difference between the minima of two consecutive scales was $24 \%$.

On asking other questions they replied that:

- $\quad$ the maximum of a job scale should be $35,5 \%$ above the minimum;

- $\quad$ the normal annual increment should be $11,1 \%$ of the basic wage; 
- a job scale should have an average of 5,3 notches, and

- $\quad$ there should be an average overlap of $13,3 \%$ between job scales.

It must further be mentioned that there was a great variation among these firms, thus indicating that there was definitely a need for guidance. It appears, however, that averages can serve as a useful basis for developing sound wage structures. However, annual notches of $11,1 \%$ cannot be right. If the maximum of the job scale were $35,5 \%$ above the minimum, and if there were 5,3 notches per scale, then the annual increment would be nearer to 6 or $7 \%$. Our respondents probably considered increases with a view to counterbalancing inflation, which in our opinion should be handled separately.

\section{Average wages according to job categories}

Respondents were requested to furnish information on the minima and maxima of wage scales for different job categories. In table 3 the averages of these, as well as the numbers involved, are given separately for employees ranging from entrance to senior level jobs.

\section{TABLE 3}

\section{NUMBER OF BLACK WORKERS INVOLVED AND AVERAGES OF WAGE SCALES FOR DIFFERENT JOB CATEGORIES}

\begin{tabular}{|l|r|r|r|r|r|r|}
\hline & \multicolumn{2}{|c|}{ ENTRANCE LEVEL } & \multicolumn{3}{c|}{ SENIOR LEVEL } \\
\cline { 2 - 7 } & \multicolumn{2}{|c|}{ SALARY IN R.p.m. } & \multicolumn{3}{|c|}{ SALARY IN R.p.m. } \\
& NUMBER & MINIMUM & MAXIMUM & NUMBER & MINIMUM & MAXIMUM \\
\cline { 2 - 7 } Unskilled & 175563 & 78,14 & 100,18 & 994 & 84,00 & 140,25 \\
Semi-skilled & 48899 & 96,54 & 144,28 & 587 & 122,25 & 164,63 \\
Skilled & 5933 & 132,31 & 201,95 & 421 & 150,64 & 246,70 \\
Clerical \& Adm. & 4887 & 128,46 & 222,62 & 709 & 174,38 & 324,21 \\
Sales workers & 801 & 153,19 & 277,93 & 465 & 382,20 & 587,40 \\
Supervisors & 1681 & 158,04 & 223,93 & 681 & 195,18 & 286,33 \\
Professional/ & & & & & & \\
graduated & 105 & 250,41 & 456,00 & 32 & 266,71 & 415,83 \\
\hline
\end{tabular}

From table 3 the following may be concluded.

- that there appears to be a fairly sound differentiation in salaries among job categories, and also between entrance and senior level jobs;

- $\quad$ that in these averages there are fairly large differences between the minima and maxima of job scales and fairly large overlaps between scales, indicating that there would be room for extra job grades in between. 
- that most Blacks are still employed in the unskilled and semi-skilled job categories, although increasing numbers are already entering the more demanding positions. The jobs they presently fill, are undoubtedly at least part of the reason for the wage gap which is so often referred to with regard to South Africa. To reduce or eliminate this gap, Blacks will first have to qualify for them to be employed in the better paid positions.

\section{Educational level of the different population groups}

The question might be asked why Blacks have not entered the higher level occupations. Tradition and culture, have certainly played their part.

A more important reason is probably to be found in the educational level of Blacks. The 1970 Census figures indicate this.

\section{TABLE 4}

\section{QUALIFICATIONS OF TOTAL S.A. POPULATION ACCORDING TO 1970-CENSUS (\%'s)}

\begin{tabular}{|l|c|c|c|c|}
\hline & WHITES & ASIANS & COLOUREDS & BLACKS \\
\cline { 2 - 5 } No scholastic education & 13,4 & 28,7 & 37,9 & 56,9 \\
Only primary school standards & 16,4 & 40,8 & 44,5 & 34,9 \\
Secondary standards without St.10 & 41,6 & 26,1 & 15,9 & 7,6 \\
Std. 10 & 21,3 & 3,2 & 0,9 & 0,3 \\
More than Std. 10 & 7,5 & 1,2 & 0,8 & 0,3 \\
\hline & 100,0 & 100,0 & 100,0 & 100,0 \\
\hline
\end{tabular}

These figures, taken from the 1970-census, give the scholastic level of the total population (those who are still at school, and not yet, at school are also included). From these figures it is evident that the educational level decreases rapidly from Whites through Asians to Coloureds to Blacks. This corresponds remarkably well to the occupational levels of different race groups shown in the next table, (these were also based on the 1970-census). 


\section{TABLE 5}

OCCUPATIONAL COMPOSITION OF S.A. POPULATION IN 1970 (\%'s)

\begin{tabular}{|c|c|c|c|c|c|}
\hline & TOTAL & WHITES & ASIANS & COLOUREDS & BLACKS \\
\hline Professional, technical \& related & 4,1 & 13,5 & 5,4 & 3,5 & 1,7 \\
\hline Administrative and managerial & 1,0 & 4,7 & 1,0 & 0,1 & 0,1 \\
\hline Clerical, sales and related & 11,3 & 38,7 & 31,9 & 9,2 & 3,7 \\
\hline Service workers & 15,8 & 7,0 & 9,4 & 18,9 & 18,1 \\
\hline Farm, forestry, fishermen $\&$ hunters & 28,6 & 6,5 & 3,8 & 17,7 & 36,6 \\
\hline Production, transport and labourers & 31,1 & 27,3 & 41,0 & 43,9 & 30,1 \\
\hline Not classifiable & 8,1 & 2,3 & 7,5 & 6,7 & 9,7 \\
\hline TOTAL ....... & 100 & 100 & 100 & 100 & 100 \\
\hline
\end{tabular}

These tables (i.e. tables 4 and 5) indicate that there is a close relationship between education and occupational level. It is only logical that these will also show a correlation to productivity and compensation. To eliminate the wage gap the sound reasons for this gap will have to be tackled first. Educational levels would thus be the starting point.

Using 1960 data Horner (1972) says that the higher job classes namely professional, technical, administrative, clerical and sales workers, constituted $43 \%$ of the total economically active population of the U.S.A., while that of South Africa is only $13 \%$. One would expect that the tendency should be in the same direction in a fast developing country like South Africa. Thus there is clearly room at the top, which will have to be filled largely by the Non-White population groups. For this however, they will have to prepare themselves. The facilities for education can be provided, but positive results can only be obtained by the children themselves. They can obviously not afford to burn down their schools as they have so often done lately, and encouragement for them to do so will clearly not be in their own interest.

\section{Starting wages according to educational requirements of jobs}

Our respondents were requested to indicate the normal starting salaries (per month) for jobs requiring different qualifications. These average starting salaries are shown in Table 6. 


\section{TABLE 6}

AVERAGE STARTING SALARIES ACCORDING TO QUALIFICATION REQUIREMENTS

\begin{tabular}{|l|r|c|c|}
\hline & $\begin{array}{c}\text { AVERAGE } \\
\text { IN R.p.m. }\end{array}$ & $\begin{array}{c}\text { \% INCREASE } \\
\text { FROM PREVIOUS }\end{array}$ & N \\
\hline Illiterate & R 74,69 & & 98 \\
Std. 4 & 84,94 & 13,7 & 94 \\
Std. 6 & 101,46 & 19,4 & 83 \\
Std. 8 & 124,95 & 23,2 & 74 \\
Std. 10 & 185,50 & 48,5 & 64 \\
B-degree & 319,77 & 72,4 & 22 \\
Post-graduate & 482,50 & 50,9 & 4 \\
\hline
\end{tabular}

From the above figures it is clear that it is far more rewarding to obtain higher academic qualifications. The average starting salary increases constantly with an increase in the qualification requirements of jobs. Furthermore, there is a tendency for the increase to become larger towards the higher qualification levels. While the difference from no schooling to Std. 4 is only $13,7 \%$ the difference from Std. 10 to a B-degree is $72,4 \%$

The correlation between educational requirements and compensation was confirmed by this data concerning the lowest and highest paid employees in these firms. The average school standard of the first group was only 2,5, and that of the latter 8,9. In the lowest paid group the average wage for illiterates was R65,75, for Std. 4's R72,33, and for Std.6's R91,43. For the highest paid group the average wage for Std. 8's was R237,16, for Std. 10's R266,41, for those with B-degree it was R384-67. The lowest paid group was also younger (26,7 compared to 40,2 years), and had less relevant experience (1,7 compared to 11,3 years).

\section{The relative importance of job requirements in different job categories}

Respondents were requested to indicate the relative importance of six job factors for seven job categories. This was done by indicating the value of each factor (in percentage form) for each job category. These factors were defined in a previous section of the questionnaire. The averages are shown in Table 7. 


\section{TABLE 7}

\section{THE EXTENT TO WHICH EACH JOB REQUIREMENT IS NEEDED IN EACH JOB CATEGORY (\%'s)}

\begin{tabular}{|c|c|c|c|c|c|c|c|}
\hline & 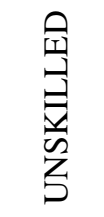 & 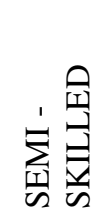 & 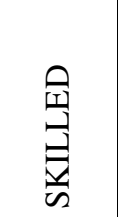 & 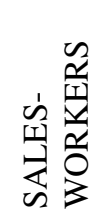 & 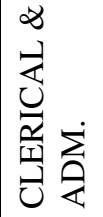 & 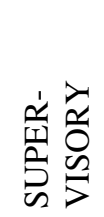 & 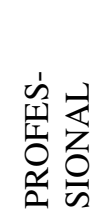 \\
\hline Mental requirements & 10 & 15 & 20 & 24 & 28 & 24 & 28 \\
\hline Physical requirements & 41 & 27 & 14 & 9 & 6 & 7 & 6 \\
\hline Knowledge requirements & 11 & 17 & 20 & 24 & 24 & 22 & 24 \\
\hline Skill requirements & 15 & 18 & 21 & 17 & 14 & 14 & 14 \\
\hline Responsibility requirements & 8 & 11 & 15 & 18 & 19 & 24 & 21 \\
\hline TOTAL .... & $100 \%$ & $100 \%$ & $100 \%$ & $100 \%$ & $100 \%$ & $100 \%$ & $100 \%$ \\
\hline
\end{tabular}

From these findings it is particularly interesting to note that while the mental requirements are increasing towards the higher level jobs, the physical requirements tend to decrease. This might indicate that in the first instance we are dealing with a psycho-physical ability factor, and in the second instance, with a psycho-physical stress factor. It may also mean that in job evaluation, where physical requirements and working conditions are often an embarrassment because they tend to show a negative correlation with wages, we need not be over-concerned, because they are actually parts of broader factors which can be taken into account through their other components.

\section{Intrinsic values of various job characteristics for different groups}

In another question participants were asked to indicate, in their opinion what relative value (a) homeland and (b) urban workers would attach to a number of job characteristics. A good basic wage and certainty that they would retain their jobs were ranked first and second respectively for both groups. They also indicated fairly large differences between homeland and urban workers with regard to preference for working amongst their own people (3rd and 11th respectively), work which gives them status (8th and 3rd respectively), and opportunity to learn and progress (9th and 5th respectively). If workers themselves feel the same about these matters, then this is something to be considered when attempts are made to create acceptable working conditions for them. 


\section{Preference for various compensation policies}

In yet another question respondents were requested to arrange thirteen possible compensation policies in a rank order. The following policies were viewed to be the soundest:

- An equitable compensation for each employee according to the requirements of the job, and the merit of the job incumbent;

- $\quad$ Pay according to the worker's contribution to the achievement of objectives;

- Internally in the correct relationship to each other and on a competitive level with comparable jobs in the labour market;

- $\quad$ Pay that would be enough to attract personnel, to retain them and motivate them.

The following policies received the least support:

- Just enough to fill the jobs and keep workers satisfied;

- $\quad$ As much as is prescribed by the law or can be negotiated with workers;

- The best that can be negotiated with workers or their organisations;

- $\quad$ At least equal to the minimum existence level, and above that according to demand and supply.

\section{Further questions}

From further questions it appeared that the wages of Blacks had increased by an average of $54,4 \%$ over the last three years, compared to $30,0 \%$ for the Whites. A less satisfactory finding is that $82,5 \%$ of our respondents felt that productivity did not keep pace with the increases in wages.

\section{CONCLUSIONS}

Some conclusions that can be drawn from these findings are the following:

- Several fringe benefits are already fairly generally provided for, while there is an awareness of the need for others. These fringe benefits constitute between 10 and 20\% of the basic wages and tend to be proportionally higher for lower paid persons. This should be taken into account when evaluating the compensation of Black workers.

- $\quad$ A large variation exists in the average wages of Black workers depending on their qualifications and the level of their jobs. This is correct but there is perhaps too much deviation among firms. 
- $\quad$ Most Black employees are employed in the unskilled job categories. To reduce or eliminate the wage gap their qualifications will have to be raised so that they can be employed in the higher level jobs.

- $\quad$ Based on the averages of existing wage structures, it would appear that job scales with maxima of $\pm 36 \%$ above the minima, with 5 to 6 notches and with overlaps of $1 / 3$ seemed to be preferred. There is not much wrong with such a wage structure, except that the overlap could perhaps be removed and replaced by extra job grades.

- An interesting tendency regarding the job factors investigated here, is that they seem to operate in pairs. As the mental requirements of jobs increase, the physical requirements tend to decrease, and as the responsibility requirements increase, the inconvenience of the physical working conditions tend to decrease. It was suggested that there might be sense in treating them as psycho-physical ability and stress factors.

Our respondents favoured a compensation policy by which an employee is compensated equitably according to the requirements of the job and the merit of the job incumbent; in accordance with the worker's contribution to the achievement of objectives; internally in the correct relationship to each other and on a competitive level with comparable jobs in the labour market. There does not seem to be much wrong with their approach to Black wages. There are, however, large differences among them. What they seem to need, is a sound compensation system to assist them in the implementation of their policies. An attempt was made to develop such a system in the investigation.

\section{SUMMARY}

This is a report on the most important findings of a questionnaire survey among employers on the remuneration of Black workers in South Africa.

Amongst other things the following was found:

- that most of the usual fringe benefits are already fairly generally provided for or that the employers are aware of the need for them;

- that wages show a high relationship to job and educational levels and that both of these will have to be raised in order to narrow the wage gap;

- that in general employers show a sound approach to the remuneration of their Black employees, but that they apparently are in need of a system by which it may be effectively implemented. 


\section{REFERENCES}

Horner, J.A. Black Pay and Productivity in South Africa. S.A. Institute of Race Relations, Sept. 1972.

Langenhoven, H.P. A system for the Compensation of Black Workers. Bloemfontein, U.O.F.S., 1977. 